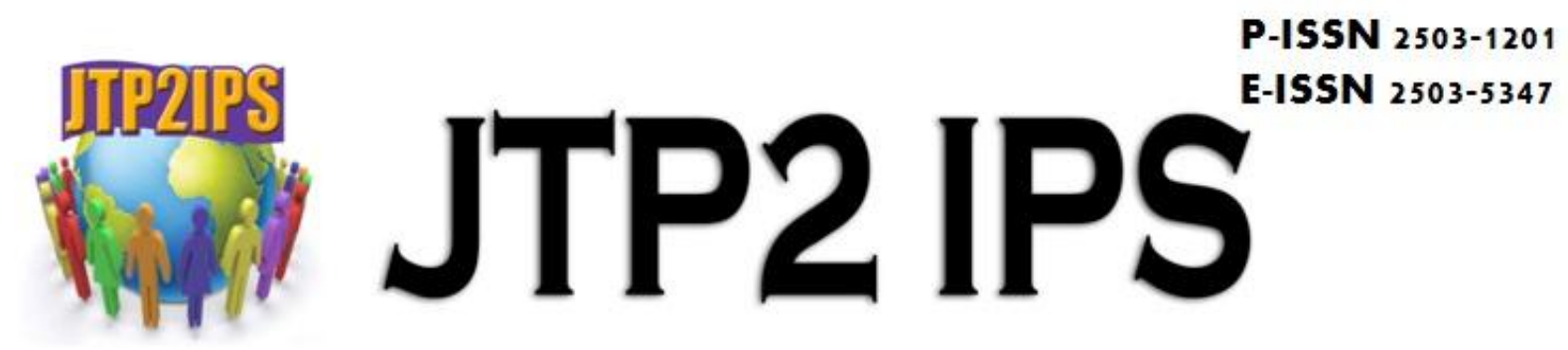

\title{
MENGENANG SEPULUH TAHUN BENCANA INDUSTRI LUMPUR LAPINDO DAN TINDAKAN KOLEKTIF PARA KORBAN
}

\begin{abstract}
Sukamto ${ }^{1}$
Abstrak

Artikel ini bertujuan untuk mengenang peristiwa luar biasa yang bernama Bencana Industri. Bencana ini berlansung cukup lama, di mana sumber semburan belum dapat dihentikan sampai kini. Menelan korban yang cukup banyak, bahkan ada desa yang terhapus dari peta, karena seluruh permukaan luluh lantak diterjang lumpur. Penyelesaian masalah sosialnya baru saja diakhiri setelah Pemerintah memberikan talangan Uang sebagai pelunasan "ganti rugi". Ganti rugi menjadi istilah yang kontroversial sebab pada dasarnya yang terjadi adalah jual beli. Tentu kedua istilah itu membawa konsekuensi masing-masing, yang tentu ada pihak yang diuntungkan sebaliknya ada pula pihak yang dirugikan. Pihak korporasi yang diuntungkan sedangkan para korban yang dirugikan.
\end{abstract}

Kata kunci: Bencana Industri, Lumpur Lapindo, Porong-Sidoardjo.

\begin{abstract}
This article aims to commemorate an extraordinary event called Industrial Disaster. This disaster occurred a long time, where the source bursts can not be stopped until now. Casualties are quite a lot, there is even a village wiped off the map, because the entire surface of the devastated hit by the mud. Settlement of sosial problems has just ended after the Government granted bail money as payment of "compensation". Compensation become a controversial term because basically what happens is buying and selling. Sure to two terms the consequences of each, which of course there are those who benefit the contrary there are also losers. Corporate parties are benefited while the victims were Hamed.
\end{abstract}

Keywords: Industrial Disaster, Lumpur Lapindo, Porong - Sidoarjo

\footnotetext{
${ }^{1}$ Prodi Pendidikan IPS Fakultas Ilmu Sosial - Universitas Negeri Malang, sukamto.fis@um.ac.id
} 


\section{PENDAHULUAN}

Berbagai kesempatan dalam Seminar atau konferensi baik untuk sejarah dan ilmu sosial dan terlebih lagi Ilmu Pengetahuan sosial tidak bosan-bosan mengungkapkan masalah bencana Industri ini tidak hanya dibiarkan begitu saja, melainkan dipetik pelajaran dan sekaligus dijadikan bahan ajar untuk sejarah maupun IPS baik di jenjang SD, SMP, SMA maupun Perguruan Tinggi. Perjuangan para korban sendiri merupakan suatu tindakan kolektif di satu pihak atau gerakan sosial di pihak lain. Tindakan kolektif dan gerakan sosial menjadi sisi perspektif tersendiri (Sukamto. 2015. Menggurat, Menggugat dan Merajut Sejarah Sosial. Malang: UM Press 151-284).

Dalam perspektif ini kata Gamson (1992 dalam Klandersmans. 2005) sebuah kerangka tindakan kolektif adalah "seperangkat keyakinan dan pemaknaan yang berorientasi pada tindakan, yang memberi inspirasi dan elegitimasi berbagai kegiatan dan kampanye gerakan sosial". Dengan kata lain, kerangka aksi kolektif (tindakan kolektif) adalah seperangkat keyakinan kolektif yang memungkinkan suatu pemikiran tercipta bahwa partisipasi di dalam tindakan kolektif tampak berarti. Gamson membedakan tiga komponen kerangka tindakan kolektif yaitu (1) rasa ketidakadilan, (2) elemen identitas dan (3) faktor agensi.

Rasa ketidakadilan muncul dari kegusaran moral yang berhubungan dengan kekecewaan, dalam korban lumpur lapindo mereka merasa bahwa hak-hak telah hilang dan terlalu sering dikhianati untuk mendapatkan ganti rugi, dalam dalam realitas ia berurusan dengan jual beli ${ }^{2}$. Perasaan ketidakadilan semacam itu menjadi raison d'etre dari beberapa gerakan sosial utama yaitu gerakan korban lumpur lapindo. Dari suatu penelitian tentang emosi menyatakan bahwa kemarahan adalah emosi yang diekspresikan oleh orang-orang yang menganggap pihak luar sebagai pihak yang bertanggungjawab atas situasi yang tidak dikehendaki (Klandersmans. 2005: 8). Tetapi untuk dapat memotivasi tindakan kolektif, kemarahan itu harus dirasakan bersama. Ini membawanya pada komponen kerangka tindakan kolektif yang kedua yaitu identitas.

\footnotetext{
${ }^{2}$ Perubahan status dari ganti-rugi menjadi jual beli berarti perubahan status dari korban menjadi penjual biasa. Perubahan ini dipandang sebagai
}

Salah satu sumbangan Lenin adalah menciptakan gagasan pentingnya organisasi gerakan, yang kemudian dikenal dengan mobilisasi kebutuhan membangun kesepakatan di antara kelompok-kelompok, yang kemudian dikenal dengan bingkai dan pembentukan identitas kolektif (Tarrow, 1998 dalam Situmorang. 2007). Perspektif teori semacam ini dapat digunakan untuk membaca gerakan perlawanan para korban lumpur lapindo sekaligus menjelaskan aktivitasnya. Betapa kelompok-kelompok korban lumpur lapindo cukup beragam, mulai nama desa yang mencakup tiga belas desa dari tiga kecamatan, sekaligus desa menjadi identitas mereka. Kelompok-kelompok yang lain adalah beda-sarkan pilihan-pilihan tawaran dari pihak korporasi atau Lapindo. Misalnya cash and carry, Cash and Resettlement, maupun di luar keduanya. Bahkan juga kelompok-kelompok mereka yang mau menerima Perpres 14 tahun 2007 dan dengan mereka yang tidak mau menerima skema sebagaimana diatur di dalam Perpres 142007.

Gerakan sosial banyak mengikuti strategistrategi tertentu salah satunya adalah yang dikenal dengan POS (Political Opportunity Structur) atau struktur kesempatan politik. Strategi atau mekanisme POS berusaha menjelaskan bahwa gerakan sosial terjadi karena disebabkan oleh perubahan dalam struktur politik, yang dilihat sebagai suatu kesempatan (Situmorang, 2007). Gerakan sosial korban lumpur lapindo tidak banyak mendapat peluang semacam itu, paling-paling dijadikan alat sementara untuk kepentingan sesaat para elit dalam pilkada contohnya.

Kalau Sydney Tarrow (1998), menekankan bahwa bentuk-bentuk ketegangan politik mengalami peningkatan ketika para pelaku perubahan mendapatkan dukungan sumberdaya eksternal untuk keluar dari masalah atau mencapai tujuan yang mereka inginkan, yaitu tujuan-tujuan gerakan. Namun dalam gerakan korban lumpur lapindo para korban tidak mendapatkan bentuk-bentuk ketegangan politik tersebut yang signifikan, ini tidak berarti tanpa dukungan sumberdaya eksternal partai politik misalnya.

tindakan yang sewenang-wenang, karenanya sebagai tindakan yang tidak adil. 
Berhasil tidaknya gerakan sosial sering kali dilihat dari segi sejauh mana mereka memenangkan pertempuran atas arti. Hal ini berkaitan dengan upaya pelaku perubahan mempengaruhi makna dalam kebijakan publik. Oleh karena itu, pelaku perubahan memiliki tugas penting dalam mencapai perjuangan melalui membuat bingkai dari masalah-masalah sosial dan ketidakadilan. Sedangkan Zald (dalam Situmorang, 2007) mengidentifikasi topik penting yang tidak hanya berhubungan dengan proses pembingkaian tetapi juga memainkan peranan penting dalam membentuk bingkai aksi. Kata Zald lebih jauh kesempatan politik dan mobilisasi, sering-kali tercipta melalui ketegangan budaya dan kontradiksi yang berlangsung lama, kemudian muncul dalam menjadi bahan proses bingkai tindakan kolektif. Misalnya keluhan-keluhan dan ketidakadilan, yang diderita bersama kemudian melahirkan aksi kolektif menjadi suatu keharusan. Padahal untuk gerakan sosial korban lumpur lapindo sebagai suatu penyebab berlangsung sangat cepat.

Adanya aktor-aktor yang berbeda dari berbagai kelompok gerakan baik yang berasal dari dalam maupun luar kelompok gerakan, dalam konstelasi beragamnya kelompok sasaran, adalah faktor yang mempengaruhi melebarnya pembingkaian. Oleh karena itu Zald menyatakan bahwa topik kedua proses pembingkaian sebagai sebuah aktivitas strategi. Keretakan dan kontradiksi budaya menyediakan konteks dan sekaligus kesempatan bagi kader-kader gerakan, yaitu pemimpin, partisipan inti aktivis dan simpatisannya. Akan tetapi juga ada sebuah proses aktif framing dan pendefinisian ideologi, simbol, peristiwa-peristiwa yang bias menjadi ikon para pengusaha moral.

Dengan merujuk pada pemikiran Tilly (1978) berbagai tindakan kolektif yang terjadi pada abad ke 19 meliputi tiga bentuk, yaitu pertama tindakan kolektif yang kompetitif, yang kedua reaktif dan yang ketiga proaktif. Melihat ketegori yang demikian aktivitas perlawanan atau gerakan sosial para korban lumpur lapindo dapat dimasukkan ke dalam kategori yang mana. Tampaknya ketiga-tiganya dapat melabeli bentuk-bentuk tindakan kolektif para korban lumpur lapindo. Mengapa hal ini terjadi sekurang-kurang sepanjang empat tahun dan

\footnotetext{
${ }^{3}$ Nota Kesepahaman atau Mou pada dasarnya tidak lebih sebagai siasat Lapindo atas Perpres 14/2007.
}

lima tahun berjalan di antara kelompok-kelompok korban lumpur lapindo menduduki ketiga-tiganya. Pertama, korban lumpur lapindo melawan secara kompetitif dalam arti diantara kelompok-kelompok perlawanan terjadi Kumpetisi, dan bahkan kompetisi itu melahirkan peran dan identitas kolektif yang beraneka ragam. Sebab seseorang korban atau sekelompok korban dapat saja mengandal kepada tidak hanya satu kelompok perlawanan melainkan dapat lebih.

Perlawanan dalam bentuknya yang reaktif dapat dibuktikan oleh sebagian sejarah kelahiran kelompok-kelompok itu sendiri yang pada dasarnya sebagian didasarkan pada reaksi atas berbagai taktik dan strategi korporatokrasi menghadapi tuntutan para korban. Lahirnya Pagar Rekontrak sebagai reaksi atas terbitnya Perpres 14 tahun 2007, lahirnya Geppres sebagai reaksi dari Nota kesepahaman yang dilakukan oleh kelompok warga korban GKLL yang melakukan MoU dengan korporasi Minarak Lapindo Jaya ${ }^{3}$.

Sedangkan tindakan kolektif sebagai bentuk proaktif dapat ditunjukkan oleh tuntutantuntutan para korban sehingga melahirkan kebijakan-kebijakan baru, baik itu untuk mengantisipasi atas serangan luberan lumpur lapindo, maupun strategi dan taktik korporasi yang diakui atau tidak sebagai penerapan prinsip-prinsip bisnis yang akan selalu mengutamakan keuntungan. Sebagai suatu pemikiran bisnis, maka keuntungan harus ada di pihak pengusaha atau korporasi dan biaya sedapat mungkin diserahkan dan dibebankan kepihak lain, terlepas mereka itu lawan bisnis atau pihak konsumen.

Menurut Smelser (1962) manusia dalam memasuki episode perilaku kolektif disebabkan dalam lingkungan sosialnya ada sesuatu yang salah. Umumnya formulasi ketegangan struktur yang dialami itu tidak bersifat sistemik. Namun tatkala berbagai ketegangan itu muncul, maka akan semakin cenderung muncul pula episode perilaku kolektif. Secara khusus kata Smelser "any kind of strain may be a determinant of any kind of collective behavior". Masih dalam pemikiran Smelser ketegangan struktural itu berkaitan dengan persoalan-persoalan misalnya fasilitas situasional, mobilisasi motivasi, 
orientasi pada norma dan orientasi pada nilai dalam gerakan.

Berbeda dengan Tilly dam Smelser, Ted Robert Gurr (1972) menunjukkan bahwa "perilaku kolektif bisa disebabkan oleh rasa ketidaksenangan. Sedangkan rasa ketidaksenangan merupakan produk dari ketidaksesuaian antara kondisi obyektif dan ide-ide atau harapan-harapan tentang kondisi tersebut. Pendek kata ketidaksenangan adalah suatu produk kesenjangan antara kenyataan di satu pihak dan harapan pada pihak yang lain. Bahkan hal ini ditambahkan oleh Oberschall, yang menegaskan bahwa ketidaksenangan juga disebabkan oleh adanya rancangan struktur sosial yang menguntungkan kelompok-kelompok tertentu, dan merugikan kelompok yang lain. Sedang dalam konteks korban lumpur lapindo, maka ketidaksenangan sebagai-mana dipikirkan oleh Gurr sebagai sesuatu yang bertubi-tubi dirasakan, dialami dan bahkan sampai kapan berakhir merupakan suatu yang tidak pernah jelas. Bahkan hilangnya harta benda, lapangan pekerjaan, pendidikan berantakan, kesehatan terus-menerus menurun akibat lingkungan makin memburuk, masyarakat tercerai berai dan masa depan merupakan sesuatu yang kasat mata dan menyelimuti para korban lumpur lapindo.

Perbedaan pendapat yang terjadi di antara Scott dan Popkin pada dasarnya disebabkan oleh perbedaan perspektif. Pertama, Scott lebih menekankan pada moral ekonomi, yang berpendapat bahwa jalan satu-satunya untuk keluar dari dominasi, yaitu dengan jalan mengamankan batas subsistennya, atau prinsip dahulukan selamat (savety first), dengan tujuan untuk meminimkan resiko, dan tetap berada dalam konteks dan sistem yang ada. Sedangkan Popkin lebih mengarahkan kepada ekonomi politik. Menurut Popkin, semua bentuk perlawanan petani bukan untuk menentang perubahan, melainkan untuk menentang kekuasaan para elit desa, petani kaya, yang mengatasnamakan komunitas tradisional demi mempertahankan institusi yang lebih menguntungkan mereka (petani kaya), dan justru lebih cenderung menghimpit kehidupan petani miskin. Dengan demikian, Popkin menolak anggapan penganut pendekatan moral ekonomi yang lebih menganggap protes dan gerakan petani sebagai reaksi defensif untuk memper-tahankan institusi tradisional mereka, dan norma-norma resi- prositas mereka dari ancaman kapitalisme dan kolonialisme.

Kedua, terletak pada unit analisisnya. Scott unit analisisnya lebih pada komunitas desa, sementara Popkin lebih kepada keluarga petani. Sedangkan Popkin unit analisisnya lebih kepada struktur kelas. Dalam gerakan sosial korban lumpur lapindo unit analisisnya terletak pada organisasi yang disebut Pagar rekontrak dan GKLL.

Ketiga, terletak pada setting penelitiannya. Scott tidak melakukan analisis pada revolusi petani, tetapi lebih pada konteks rebellion, pemberontakan petani di dalam konteks logika mempertahankan batas keamanan subsistensi, termasuk perlawanan terhadap kolaborasi interklas, di mana perlawanan yang demikian itu terjadi terutama pada saat kegagalan panen atau perang. Dalam keadaan demikian itu, reaksi petani mengingat situasinya, sering terbatas pada perlawanan keras kepala tetapi pasif, membuat petisi, melarikan diri atau menjadi penyamun. Berbeda dengan Scott, Paine melihat struktur desa sebagai variabel dari perlawanan petani, sebab pusat perhatiannya pada bentuk konflik kelas terutama struktur kelas yang bersumber dari pendapatan petani kelas bawah dan buruh tani dengan petani kelas atas yang tidak ikut mengolah tanah.

Jika pada masa Orde Baru UU Pokok Agraria hanya dipandang sebagai masalah teknis, maka pada masa Reformasi Susilo Bambang Yudhoyono, UU Pokok Agraria justru dikesampingkan dengan bukti dipaksakannya Perpres Nomor 14 tahun 2007 yang bukan semata-mata menabrak, melainkan mengesampingkan. Pada hal di era Reformasi semasa pemerintahan Gus Dur Ia berupaya melaksanakan Land Reform sebagaimana UU Pokok Agraria dengan serius, bahkan Gus Dur dalam kaitannya dengan korban lumpur Lapindo menyarankan dan bahkan menyerukan untuk tidak menjual tanahnya, lebih-lebih kepada pihak korporasi.

Sebagai faktor pemicu (precipitation factors) yang banyak terjadi pada masa pasca reformasi termasuk di dalamnya berkaitan dengan penanganan lumpur lapindo, yaitu tindakan aparatur desa sampai dengan kecamatan dan kabupaten yang korup, otoriter atau tidak demokratis sehingga terjadi ketidakadilan.

Gerakan Sosial di Eropa telah mengambil arah yang berbeda, dengan label teori gerakan sosial yang baru, dengan sudut pandang yang 
baru pula (Pichardo dalam Klandersman, 2005). Gerakan sosial tidak dipandang sebagai kegiatan politik dengan cara lain, tetapi sebagai orangorang yang mencari sebuah identitas kolektif baru. Bahkan sebagian mengatakan dan menggunakan istilah "gerakan identitas" (identity movements, Cohen. 1995). Dengan mengesampingkan pertanyaan tentang apakah gerakan ini "baru" dalam segala hal ataupun apakah pencarian identitas itu merupakan sesuatu yang spesifik untuk gerakan ini, dapat dijelaskan bahwa literatur gerakan sosial baru telah menarik perhatian para pengkaji gerakan sosial ke arah aspek lain dari gerakan sosial, yaitu gerakan sosial sebagai sponsor pemaknaan dan pembawa identitas. Konstruksi sosial tentang makna menjadi bagian sentral teori gerakan sosial, seperti ditunjukkan oleh publikasi Eyerman dan Jamison (1991, Morris dan Mueller (1992), Larana dkk (1994), Johnson dan Klandermans (1995). Keempat publikasi tersebut menempatkan tahap konstruksi makna, pembentukan identitas dan pembentukan pusat kultur di dalamnya. Konstruksi sosial tentang makna pembentukan identitas, dan wacana publik semuanya adalah konsep yang masih berhubungan dengan pendapat lain tentang gerakan sosial.

Merujuk pada pemikiran GSB (Gerakan Sosial Baru) yang ditandai oleh upayanya untuk meninggalkan dan menanggalkan orientasi ideologis sebagaimana berkembang pada gerakan sosial dahulu, namun lebih menekankan pada isu-isu spesifik non materialistik, GSB tampil sebagai per-juangan lintas kelas maka tindakan kolektif yang terjadi di Lumpur Lapindo dapat dikategorikan pada GSB.

Lebih jauh Singh (2001) menambahkan bahwa GSB pada dasarnya merupakan bentuk respon terhadap hadir dan menguatnya dua institusi yang menerobos masuk ke hampir semua relung kehidupan warga, yakni negara (the state) dan pasar (the market). Karena itu GSB membangkitkan isu pertahanan diri komunitas dan masyarakat untuk melawan ekspansi aparat negara dan pasar yang makin meningkat (Suharko. 2006). Itu semua membutuhkan suatu pengorganisasi dan kepemimpinan, agar terjadi koordinasi dan komunikasi yang signifikan, di samping berbagai tujuan dapat dicapai. Selanjutnya akan dikemukakan bagaimana peranan kepemim- pinan di dalam studi tindakan kolektif dan juga gerakan sosial.

\section{PEMBAHASAN}

\section{Perspektif Peranan Pemimpin dalam Tindakan Kolektif}

Masalah kepemimpinan dan organisasi merupakan masalah yang krusial dalam sepak terjang tindakan kolektif maupun gerakan sosial. Memang perlu disadari bahwa bukanlah pemimpin yang melahirkan tindakan kolektif atau gerakan sosial, tetapi justru sebaliknya melalui gerakan sosial dan tindakan kolektif akan melahirkan seorang pemimpin. Pagar Rekontrak dan GKLL representasi gambaran tersebut.

Penelitian tindakan kolektif warga korban lumpur lapindo ini, juga membuktikan bahwa peranan pemimpin adalah sangat penting sekali, bukan hanya pada tahap mobilisasi motivasi tetapi juga dalam setiap fase tindakan kolektif, khususnya dalam fungsi memotivasi dan melakukan aksi. Agak berbeda dengan teori Smelser yang menempatkan peranan pemimpin lebih banyak pada fase mobilisasi motivasi, maka studi tindakan kolektif korban lumpur Lapindo justru melihat peran pemimpin gerakan itu berada dalam setiap fase tindakan kolektif. Dengan demikian, kepemimpinan itu diperlukan sejak perancangan suatu aksi, sosialisasi, motivasi, tahap ketegangan struktural, aktivitas pertumbuhan dan persebaran kepercayaan umum, aktivitas mobilisasi, dan pemeliharaan konsistensi komitmen dari jejaring gerakan.

Pemimpin dalam Tindakan kolektif bagi korban lumpur lapindo sangat penting dan menentukan, bagaikan roh di dalam suatu organisme. Selama ada pemimpin, maka selama itu pula gerakan akan dapat hidup, begitu pula sebaliknya. Namun tatkala seorang pemimpin ditahan, maka muncul pula di antara mereka untuk mengambil alih kepemimpinan. Dalam tindakan kolektif warga korban lumpur memang tidak tunggal. Kelompok atau kolek-tivitaskolektivitas warga korban dapat dicon-tohkan Pagar Rekontrak oleh Haji Sunarto SE, Gerakan Korban Lumpur Lapindo (GKLL) oleh Djoko Suprastowo, Gerakan Pendukung Pera-turan Presiden oleh Mahmudah Fatkiyah, Besuki Korban Lumpur oleh Abdul Rokhim, Pagar Betis oleh Cak Irsyad dan berbagai kelompokkelompok kecil lainnya misalnya Tim, 5, Tim 6, Tim 9, tim 16, dan sebagainya. 
Apabila Pagar Rekontrak, mereka berada di dalam satu kelompok pengungsian, dengan demikian struktur pengorganisasian ditingkat bawah misalnya RT digantikan dengan Ketua Blok, mereka sebagai pengkoordinir semua warga pada tingkat RT, kemudian langsung kepada pengurus Paguyuban. Tetapi untuk GKLL setiap desa diwakili oleh seorang koordinator lapangan (korlap) yang langsung berhubungan kepada pengurus gerakan. Di dalam gerakan GKLL struktur organisasi ada Ketua, Sekretaris, Bendahara dan di bawah pendampingan Cak Nun.

Sedangkan bentuk kepemimpinan pada Pagar Rekontrak dilakukan musyawarah setiap kumpul-kumpul di malam hari, sedangkan pada GKLL mereka mempunyai pangkalan di balai kantor Kecamatan Tanggulangin. Namun pernah juga berkantor di tempat lain. Strategi dan taktik para pemimpin warga korban lumpur lapindo memiliki corak sendiri-sendiri.

Penelitian ini juga menemukan konflik internal di antara para pemimpin gerakan baik yang terjadi di Pagar Rekontrak maupun di GKLL, contohnya Geppres sebagai konflik atas pilihan teknis jual beli yang Cash and Carry (C n C) dan yang Cash and Resettlement (C n R). Namun demikian konflik itu berarti setiap kelompok itu memecahkan diri ke dalam suatu kolektivitas tersendiri. Berbeda dengan GKLL, Pagar Rekontrak konflik internal terjadi mengeras tatkala pembagian insentif yang di antara mereka memandang mereka masingmasing merasa berhak untuk menerima lebih dari yang ditentukan di dalam musyawarah.

Perbedaan mencolok di antara Pagar Rekontrak dan GKLL, yaitu Pagar rekontrak hanya beranggotakan sebagian besar dari satu desa yaitu desa Reno kenongo, sedangkan GKLL yang semula lebih didominasi oleh mereka yang tinggal di Perum Tanggul Angin Sejahtera (Perumtas), namun kemudian ditambah dengan desa-desa yang lain dengan diwakili atau representasi dari desa masing-masing yang berjumlah $11 \mathrm{desa} /$ kelurahan seperti tampak yang menanda tangani Nota Kesepahaman antara GKLL dengan Lapindo atau Minarak Lapindo Jaya, untuk Minarak di bawah komando Andi Darussalam.

\footnotetext{
${ }^{4}$ Terutama untuk dua kelompok kolektivitas Pagar Rekontrak danGKLL, sedangkan beberapa
}

Penelitian tindakan kolektif korban lumpur di Porong ini juga membuktikan, bahwa peranan pemimpin adalah sangat penting sekali, bukan hanya pada tahap mobilisasi motivasi tetapi juga setiap fase, khususnya dalam fungsi aksi-aksi kolektif dilaksanakan. Bagi warga korban lumpur Porong, pemimpin itu ibarat roh suatu organisme. Selama ada pemimpin, maka selama itu pula gerakan akan dapat hidup, begitu pula sebaliknya. Gerakan sosial korban lumpur Porong itu memiliki satu pemimpin di tingkat pusat gerakan, kemudian diperkuat pada pemimpin-pemimpin di level ke dua atau level berikutnya.

Perjuangan untuk melawan korporasi dan negara dilakukan secara terbuka, maka gerakan atau aksi kolektif tersebut harus memiliki pemimpin, atau diperlukan kepemimpinan, baik pemimpin dari dalam maupun dari luar komunitas tersebut. Kasus korban lumpur di Porong, menunjukkan cukup banyak mempunyai pemimpin. Setiap kelompok atau kolektivitas tentu memiliki seorang pemimpin, bahkan lebih daripadanya. Pagar Rekontrak oleh Haji Sunarto SE, Pitanto, Bambang Wuryanto, Yudo Wintoko, Yuliati dan Kaminah, GKLL oleh Djoko Suprastowo, Choirul Huda, Kisdianto dan sejumlah Koordinator Lapangan yang berasal dari hampir seluruh desa dan kelurahan dan bahkan setiap RW pun yang menjadi korban. Begitu pula kelompok Siring Barat oleh Bambang Kuswanto, Besuki Timur oleh Cak Irsyad, Geppres oleh Mahmudatul Watkiyah.

Oleh karena itu kelompok-kelompok korban lumpur Lapindo secara organisatoris cukup kuat ${ }^{4}$. Sebagaimana para teoretisi Mobilisasi Sumber Daya (MSD) berpendapat bahwa semua masyarakat dapat sewaktu-waktu merasa tidak puas sebagai akibat penindasan atau perlakuan tidak adil. Oleh karena itu berhasil tidaknya gerakan sosial atau tindakan kolektif juga dipengaruhi oleh tersedianya seorang pemimpin dan tersusunnya suatu organisasi, sehingga setiap urusan dapat dan ada yang menangani dengan baik (Mc. Carthy and Zald. 1972; Oberschall, 1973, 1993). Seorang pemimpin bersama perangkat organisasinya menjadi penentu keberhasilan dalam tindakan kolektif.

kelompok yang lain rentan atas perebutan kepemimpinan. 


\section{Organisasi di dalam Tindakan Kolektif}

Fakta di lapangan menunjukkan bahwa kedua organisasi yang bernama Pagar rekontrak dan GKLL termasuk organisasi yang paling stabil dibanding dengan organisasi-organisasi yang lain Geppres, Tim 9, Tim 16, Kelompok Bambang Siring dan Pagar Betisnya Cak Irsyad. Smelser telah menyinggung peran organisasi ketika ia menjelaskan tentang proses mobilisasi. Dalam proses mobilisasi dikatakan bahwa para pemimpin akan berusaha memobilisasi partisipasi ke dalam tindakan yang terorganisir. Namun tentu makna dari pernyataan ini, bukan berarti suatu tindakan kolektif memerlukan organisasi yang jelas dan formal. Pandangan Smelser di atas berbeda dengan pandangan Charles Tilly, yang menempatkan organisasi justru sebagai persyaratan penting bagi terjadinya tindakan kolektif. Organisassi dalam pengertian Tilly adalah berupa "well-defined groups", organisasi inilah yang kemudian berperan untuk mengelola interest ke dalam proses mobilisasi tinda-kan kolektif, demikian Tilly.

Bagaimana dalam kaitan dengan tindakan kolektif warga korban lumpur Lapindo? Sebagaimana data lapangan yang ditemukan, peran organisasi sangat menentukan dalam memperjuangkan hak-hak para korban lumpur. Hal ini terlebih nampak dalam berbagai upaya untuk melakukan negosiasi maupun bentukbentuk gerakan sosial atau tindakan kolektifnya.

Menjelang pertengahan tahun 1960-an teori "mobilisasi sumber daya" muncul sebagai sebuah terobosan besar, di mana teori ini telah menyingkirkan ambiguitas yang muncul di dalam "model ketegangan struktural" sepanjang itu. Bagi teori mobilisasi sumber daya tidak jadi soal entah ketegangan struktural eksis atau secara obyektif atau hanya angan-angan para pengikut sebuah gerakan, entah persepsi tentang ketegangan dan tujuan sebuah gerakan rasional atau tidak, atau bentuk simbolis mana yang diberikan oleh pengikut sebuah gerakan kepada ketegangan yang ada (Robert Mirsel. 2004).

Yang menjadi fokus perhatian mobilisasi sumber daya adalah tindakan-tindakan yang pada umumnya rasional, yang dilakukan oleh para pengikut sebuah gerakan untuk membuat gerakan itu berhasil. Agar menjadi efektif tindakan-tindakan ini hampir selalu harus dilakukan oleh organisasi-organisasi gerakan. Model mobilisasi sumber daya berusaha menggantikan studi gerakan (yang dilihat dari segi aliran pemikiran, ideologi, wacana, motivasi dan tindakan yang dilakukan oleh individu) dengan studi tentang organisasiorganisasi gerakan kemasyarakatan. Max Weber (dalam Mirsel. 2004) istilah atau teori mobilisasi sumber daya menempatkan rasionalitas (meansrationality) sebagai nilai tambah, yakni dengan menempatkan analisis tentang penggabungan aneka bentuk, strategi, dan taktik organisasi secara sengaja dan sadar dengan tujuan-tujuan yang mau dicapai.

Robert Mirsel (2004) menempatkan elemenelemen kunci dari setiap gerakan adalah organisasi-organisasi gerakan; bukan individuindividu. Organisasi-organisasi ini merupakan unit penggerak dari sebuah gerakan sosial atau tindakan kolektif dan menjadi obyek utama dan paling penting dalam sebuah penelitian, demikian dikutip dari Zald dan Ash (1966). Penelitian yang dilakukan dalam kerangka teori mobilisasi sumber daya sering terdiri dari studi organisasiorganisasi gerakan tertentu. Metode yang digunakan adalah studi kasus mengenai organisasi, atau studi perbandingan mengenai beberapa organisasi, dan bukannya survei mengenai perilaku-perilaku individu.

Tetapi, penulis juga menemukan bahwa warga korban lumpur Lapindo yang sebagian juga lemah, meski dalam berbagai hal perjuangan awal begitu kompak dan kohesif, karena merasa senasib sepenanggungan, namun dalam prosesnya juga terindikasi rentan perpecahan, gampang dipecah belah dan mudah diadu domba oleh pihak luar maupun pihak lawan yang memanfaatkan pihak luar (pihak Lapindo). Hal ini tampak seringnya terjadi perpecahan, ketidakharmonisan, contoh untuk GKLL yang semua 3000 kepala keluarga (berkas) setelah menanda tangani "Nota Kesepahaman" keanggotaan terpecah menjadi dua yaitu GKLL dan Geppres, sedang Pagar Rekontrak perubahan nama dari Pagar Rekontrak menuju Pagar Rekorlap, bukan semata-mata dikarenakan penerimaannya terha-dap Perpres 14 tahun 2007, melainkan juga terjadi perebutan insentif. Begitu di antara BKL (Besuki Korban Lumpur) dengan Pagar Betis (Paguyuban Arek Besuki Timur Siaga), yang seolah-olah dahulu jalan Tol sebagai pemisah, tetapi kini tanggul dan statusnya yang berbeda akibat Perpres 48 tahun 2008. Begitu pula pendapat Jeffrtey M. Paige yang mengatakan bahwa petani kecil itu sulit melakukan gerakan bersama dan dapat dengan 
mudah dipecah belah dan diadu domba tampaknya berlaku pula untuk menjelaskan kasus perjuangan warga korban lumpur lapindo di Sidoarjo.

Melalui teori kekerasan politik dari Ted Gurr, fenomena perjuangan atau gerakan sosial atau tindakan kolektif warga korban lumpur Lapindo dapat pula dielaborasi. Kekerasan politik sebagaimana dimengerti/dikonsepkan oleh Ted Guur begitu luas, namun substansinya sebetulnya sebatas tindakan yang dilakukan oleh seorang aktor dan atau kelompok aktor yang melawan kebijakan Negara maupun Korporasi. Penjelasan yang dapat diperoleh melalui "teori kekerasan politik" Ted Gurr, dapat dimulai melalui asumsinya bahwa semua fenomena politik termasuk tindak kekerasan politik berawal dari pikiran manusia, oleh sebab itu penyebab kerusuhan berasal dari faktor psikologis, yaitu perasaan dan kekerasan orang mengenai kekecewaan atau ketidakpuasan (Bert Klandermans. 2005).

Ted Gurr (1972) memahami bahwa kekerasan politik terjadi ketika banyak anggota masyarakat menjadi marah, khususnya jika: (1) kondisi praktis dan kondisi budaya yang ada mendorong terjadinya agresi terhadap sasaransasaran politik yang dituju; (2) terdapatnya jurang pemisah antara harapan dan kenyataan atau kemampuan memenuhi kebutuhan yang diinginkan. Jurang pemisah itulah yang melahirkan suatu kekecewaan relatif. Dengan kata lain, jika semakin kecil kemampuan yang dimiliki seseorang untuk memenuhi harapan, semakin besar pula kekecewaan relatif yang dideritanya.

Pengorganisasian kelompok-kelompok korban dapat dikelompokkan menjadi tiga, yang pertama kelompok desa Renokenongo dan sekitarnya yaitu Jatirejo, Siring dan Mindi dan yang kedua adalah kelompok Tanggulangin Kedungbendo dan sekitarnya serta yang ketiga kelompok Siring dan Besuki. Ketiga kelompok ini mem punyai karakteristik yang berbeda, yang pertama daerah pertanian yang diselingi beberapa pabrik atau perusahaan dan yang kedua adalah daerah kerajian dan beberapa pabrik disekitarnya. Untuk yang ketiga yang daerah pertanian dengan petani tambak yang paling dominan.

\section{Kelompok sebagai Satuan Kolektif}

Kelompok pertama yang menjadi pengungsi paling lama di daerah pengungsian Pasar Baru Porong yang dikenal dengan kelompok Paguyuban Renokenongo menolak Kontrak (Pagar Rekontrak), sedang yang kedua sebagian besar domisili di daerah perumahan Tanggulangin Sejahtera I. Kelompok ini memiliki warga yang campuran cukup bervariasi mulai dari PNS, PebABRI, pensiun, para pengrajin, buruh pabrik.

Dari ketiga kelompok ini mempunyai perjalanan sejarah pengorganisasian yang relatif tidak sama kelompok pertama sejak terjadi luberan lumpur Lapindo proses penanganan melalui mekanisme perangkat pemerintah mulai dari bawah RT, RW sampai dengan Kelurahan atau Kepala desa, hal ini masih terus berlangsung sampai mereka berada dalam pengungsian. Bahkan mereka yang berasal dari RT yang sama juga berada dalam lokasi pengungsian yang sama yaitu Blok atau Los Pasar Baru Porong. Namun ketika menanggapi Perpres 14 Tahun 2007, kelompok ini berbeda pandang dengan pimpinan Kelurahan, oleh karena itu dengan tetap memfungsikan kepengurusan ke RT-an dilanjutkan dengan Paguyuban yaitu Pagar Rekontrak, hanya perbedaannya tidak menggunakan struktur ke RWan.

Sebenarnya kelompok-kelompok berdasarkan ke-RT-an akan dilanjutkan di tempat tinggal yang baru yang bernama Reno Joyo, tetapi karena tempat tinggal di lotere, maka mereka akhirnya tidak tinggal di dalam RT yang sama. Apa yang dilakukan oleh GKLL berbeda dengan apa yang dilakukan oleh Pagar Rekontrak.

Kelompok yang tergabung di dalam GKLL terdiri anggota-anggota masyarakat yang lebih heterogen, di mana lingkungan masyarakatnya tidak homogen sebagai mana kelompok Pagar Rekontrak, melainkan lebih bervariasi mulai dari para buruh pabrik, pedagang, pegawai pemerintah dan pensiun.

Tindakan kolektif memiliki sejarahnya sendiri, mulai dari kelahirannya, kematangan, kedewasaan, rutinitas, bahkan kegagalan atau kematiannya sendiri, sehingga seolah-olah tindakan kolektif dapat digambarkan mempunyai biografi kehidupannya sendiri. Tidak seperti konsep perubahan sosial, gerakan gerakan sosial dan aksi-aksi kolektif memiliki sebuah individualitas historis yang spesifik 
dalam masyarakat. Oleh karena itu tidaklah aneh jika gerakan sosial atau tindakan kolektif memiliki sebuah karir dalam rentang waktu kehidupan. Dengan demikian tindakan kolektif atau gerakan sosial memiliki awal historis dan juga mengalami kemajuan, perkembangan puncak hingga mengalami kematian sendiri.

Dalam alur pemikiran ini, gerakan sosial korban lumpur lapindo mengekspresikan usahausaha kolektif masyarakat untuk menuntut kesetaraan dan keadilan sosial dan mencerminkan perjuangan-perjuangan masyarakat untuk membela identitas-identitas dan warisan kultural mereka. Aksi-aksi kolektif korban lumpur merupakan kenyataan yang esensial dan terus ada dari masyarakat, sejauh masyarakat itu ada. Dalam konteks ini dibutuhkan imajinasi sosiologis untuk menyadari bahwa, sebagaimana juga yang berlaku untuk kasus lumpur lapindo terus abadinya problem tatanan dan kekacauan sosial, problem konformitas dan penyimpangan, kebebasan dan kontrol, dan kejahatan dan hukuman yang bersifat universal dan ada di mana-mana di semua masyarakat, di setiap perkembangan mereka, gerakan sosial dan aksi kolektif tengah dan telah menjadi sebuah kekuatan universal dari lembaga, khas historis dalam masyarakat (Ibid).

Berbagai pertemuan dilakukan baik antara para korban untuk mendapatkan kesepakatankesepakatan atas tuntutan, begitu pula pertemuan antara kelompok-kelompok korban dengan pihak Minarak lapindo Jaya, kepada BPLS maupun kepada pihak-pihak pemerintahan sendiri mulai dari Kepala Desa, kepada Camat, Bupati, dan Gubernur. Tidak jarang kepada presiden pun diperjuangkan untuk dapat bertemu dan berunding, walaupun tidak terlalu mudah untuk dapat bertemu dengan presiden.

Manakala pada tingkat perundingan tidak mendapatkan hasil yang dapat memuaskan semua pihak tidak jarang lalu meningkat pertemuan atau perundingan berubah rupa menjadi perdebatan. Perdebatan demi perdebatan telah terjadi di antara pihak yang pihak yang kepentingan untuk mendapatkan haknya masing-masing. Memang semua entitas atau para pihak yang terlibat merasa berhak untuk mendapatkan perlindungan dan pemenuhan hakhaknya. Terlepas apakah itu entitas yang berupa individu maupun lembaga-lembaga, apakah lembaga masyarakat, lembaga ekonomi dan lembaga bisnis dan lembaga pemerintahan itu sendiri.

Tampaknya demonstrasi juga dipandang bagian dari alat komunikasi dan sekaligus alat untuk mendesakkan kemauan dan tuntutan atas hak-haknya. Namun pengalaman demonstrasi juga menjadi darasi bagi kolektivitaskolektivitas itu sendiri. Oleh karena itu selama 5 tahun lebih ratusan demonstrasi telah pula dilakukan. Mengapa sampai ratusan kali sebab memang kelompok-kelompok korban yang jumlahnya cukup banyak mendesakkan keinginan dan kemauannya serta tuntutannya untuk segera mendapatkan hak-haknya, Mulai dari kelompok korban desa Siring, desa Jatirejo, desa Renokenongo, desa Mindi, desa Besuki baik barat dan Timur jalan Tol. Berbagai lokasi dijadikan tempat untuk melakukan demonstrasi, mulai yang berada di tingkat lapangan dan atau lokal sampai dengan tingkat nasional. Pada tingkat lapangan dan atau lokal bisa dilakukan di tanggul-tanggul dan tanah-tanah yang dahulu menjadi milik dari para demonstran. Bahkan sampai dengan di depan dan di tempat-tempat strategis misalnya jalan depan perkantoran sampai di gedung DPR, Bupati, Gubernur dan lain sebagainya.

Di samping para pihak utamanya para korban yang dengan semangat menyala-nyala untuk melakukan pertemuan, perundingan dan tidak jarang meningkat menjadi perdebatan. Perdebatan ini pun tidak jarang malah membuat jalan buntu suatu perundingan atau bahkan karena masing-masing pihak bertahan pada pilihan pendapatnya sendiri-sendiri. Ada pula yang mendiamkan segala sesuatu urusan, apakah untuk melengkapi syarat-syarat yang dituntut oleh pihak sertifikasi dan verifikasi sebagai syarat sahnya jual beli.

Antara kelompok korban yang satu dengan kelompok korban yang lain tidaklah sama penyikapannya terhadap penanggulan yang dilakukan oleh pihak Lapindo. Suatu misal ada kelompok korban yang menghendaki tanggul atau penanggulan harus dilakukan namun pada pihak kelompok korban yang lain tidak menghendaki penanggulan, karena ini dipandang merugikan kelompok korban yang lain. Oleh karena itu tidak jarang terjadi mulai adu mulut, pertengkaran dan penjebolan tanggul tanggul tertentu. Penjebolan tanggul ini kadang kala juga dilakukan oleh calon-calon korban lumpur. 
Penyelesaian masalah yang berlarut-larut memungkinkan para pihak untuk melakukan rekayasa-rekayasa tertentu. Salah satu di antaranya adalah merekayasa surat berkaitan dengan luas tanah, luas bangunan atau bahkan status tanah yang semula sawah lalu dikatakan pekarangan, ladang atau tanah kering. Hal ini memang banyak terjadi sampai-sampai pihak MLJ tidak percaya dan bahkan sampai mendapatkan bantuan misalnya dari MH Ainun Najib untuk para pihak disumpah atas pernyataan dan atau berkaitan dengan surat-surat yang menerangkan tentang tanah dan bangunan.

Berkaitan dengan semburan lumpur, kemudian dilakukan penanggulan dengan harapan dapat memperkecil daerah atau areal yang terdampak. Namun penanggulan tidak selalu ditanggapi positif oleh berbagai pihak ada pula yang dalam pengakuannya menjebol tanggul agar daerah atau tanah terkena dampak, dengan harapan lalu mendapat ganti rugi. Hal demikian tidak jarang malah memberi peluang untuk benturan dan bentrokan antar warga di satu pihak mempertahankan tanggul dan di lain pihak ingin menjebol tanggul.

Yang menarik salah satu bentuk perlawanan dari pihak korban adalah suatu sikap dan atau perilaku yang mengambil kesempatan di setiap kesempitan dan kesempatan. Memperluas luas tanah, luas bangunan atau mengubah status tanah sawah yang dijadikan ladang dan ladang yang diberi dan dijadikan bangunan dan lain sebagainya. Bahkan yang menarik adalah pembangunan dilakukan tatkala sudah terjadi peluberan lumpur dan tanah ini dilarang atau tidak diijinkan oleh BPLS untuk dibangun, bahkan diancam kalaupun ada bangunan tanah bangunan akan tetap dihargai sebagai tanah sawah saja.

Kesadaran dan keyakinan kolektif adalah kesadaran dan keyakinan yang dimiliki bersama, sedangkan tindakan/aksi kolektif adalah kegiatan yang dilaksanakan secara bersamasama (Klandermans 2005) Baik masyarakat maupun gerakan sosial merupakan konstruksi dan masing-masing memvalidasi otentisitas eksistensi yang lain. Jika masyarakat merupakan sebuah entitas sosial yang bersifat kolektif, hal itu bisa demikian karena masyarakat senantiasa dibentuk oleh aksi-aksi sosial kolektif (Singh. Rajendra. 2010).

Ditinjau dari perspektif ini harus diakui bahwa sifat imanensi dari gerakan sosial dan kondisi-kondisi sosial dasar yang menumbuhkan gerakan-gerakan sosial cenderung terletak begitu dalam dan tak terpisahkan dengan kontradiksi-kontradiksi dan konflik-konflik struktural sosial yang relatif permanen, dan yang secara umum tak terelakkan dan terus ada dalam proses pembentukan masyarakat (Singh. Rajendra. 2010).

Tindakan kolektif warga korban lumpur lapindo bukanlah tindakan yang istimewa, bukan pula gerakan sosial yang khusus dan istimewa, sebab di mana saja di wilayah Indonesia, sejauh wilayah itu sebagai wilayah pemukiman yang padat, lalu di semburi lumpur seperti itu setiap penghuni pasti marah dan menuntut hak. Hal ini menjadi lain manakala semburan lumpur itu terjadi di tengah-tengah hutan belantara, palingpaling binatang-binatang penghuni hutan itu yang bermigrasi.

Studi mengenai gerakan sosial dan aksi kolektif bisa berbuah jika dijalankan dalam parameter sebuah perspektif tertentu yang luas mengenai masyarakat dan gerakan sosial. Perspektif yang tepat untuk menangani dan menjelaskan data gerakan sosial harus mengaitkan, dan ini harus tekankan, tentang konsepsi masyarakat dengan konsepsi gerakan sosial. Gerakan sosial dan masyarakat merupakan dua wajah dari koin yang sama yaitu "dunia sosial" (Singh. Rajendra. 2010).

Dalam suatu pertanyaan apakah semua aktor yang terlibat di dalam tindakan kolektif atau aksi-aksi kolektif di Porong itu semua berorientasi pada norma? Jawabannya tidak semua aktor mendasarkan pada orientasi norma. Bahkan dapat dikatakan bahwa orientasi para aktor dalam tindakan kolektif tersebut banyak yang mendasarkan pada resources atau materi tertentu. Jika diajukan kategori tipe aktor menjadi tiga yaitu tipe idealis, tipe pragmatis dan tipe oportunis. Tipe pertama cocok dengan teori Smelser sedang dua tipe berikutnya cocok dengan teori Tilly.

Berdasarkan hasil penelitian dapat diketahui bahwa ketiga tipe tersebut saling kerja sama dalam mengejar kepentingannya. Dengan demikian dapat dikatakan bahwa tindakan kolektif para korban lumpur itu bagi aktor tertentu dapat menjadi sumber yang bisa diambilnya.

Tindakan kolektif atau gerakan sosial korban lumpur lapindo dapat dimasukkan ke dalam kategori gerakan sosial lama dan sekaligus baru. Berada dalam kategori lama, karena tindakan 
kolektif itu berkaitan dengan pemenuhan kebutuhan ekonomi dan aspek materiil yang lain. Sedangkan dianggap gerakan sosial baru, karena ia juga mengusung isu isu yang berkaitan dengan humanitas, budaya dan keadilan, dan hal-hal lain yang bersifat non materialistik. Tujuan gerakannya universal, yakni untuk mempertahankan esensi manusia dan memproteksi diri dan kondisinya untuk mencapai kehidupan yang lebih baik (Singh, Rajendra. 2010).

Identitas, dengan sendirinya, merupakan suatu unsur kunci dari kenyataan subyektif dan, sebagaimana semua kenyataan subyektif, berhubungan secara dialektis dengan masyarakat (Berger dan Luckmann. 1990). Identitas dibentuk oleh proses-proses sosial. Begitu memperoleh wujudnya, ia dipelihara, dimodifikasi, atau malahan dibentuk ulang oleh hubunganhubungan sosial. Proses-proses sosial yang terlibat dalam membentuk dan mempertahankan identitas ditentukan oleh struktur sosial (Ibid).

Identitas lokal termasuk dalam kebudayaan lokal, begitu pula membunuh kebudayaan lokal sama artinya dengan membunuh identitas lokal. Demikian pula sebaliknya menghidupkan kembali budaya lokal sama artinya dengan menghidupkan kembali identitas lokal, sebab identitas lokal merupakan unsur yang tidak dapat dipisahkan dari kebudayaan. Dengan demikian bagaimana dengan tenggelamnya desa-desa oleh lumpur lapindo, ini juga dapat dimengerti sebagai menenggelamkan identitas lokal itu sendiri. Oleh karena itu para korban lumpur lapindo yang mencoba bertahan, berkumpul, dan bergabung dengan rekan-rekannya dan bermaksud membangun kehidupan kembali dalam suatu tempat baru, ini juga berarti para korban lumpur lapindo mencoba menghidupkan dan atau membangun kembali identitasnya yang selama ini hilang. Identitas, kata Stuart Hall, tidak pernah stabil, tidak pernah sempurna, ia selalu dalam proses menjadi, ia selalu dibangun dari dalam (Piliang, 2011). Identitas-identitas yang demikian ini pulalah yang terjadi pada gerakan sosial korban lumpur lapindo.

Identitas itu ada bila terdapat kesamaan, konsistensi, dan kontinuitas antara sebuah entitas dengan genusnya; sebaliknya adalah ketidaksamaan, keunikan dan otensisitas dengan entitas-entitas lainnya. Sebagai sebuah konsep kebudayaan, identitas menjelaskan tentang mata rantai masa lalu dengan masa kini, baik secara sosial, politik, ekonomi maupun kultural (Ibid).
Identitas merupakan ikhtisar masa lalu, yang dimiliki bersama oleh individu atau sekelompok individu, yang menjadi pembeda antara individu atau kelompok dengan individu atau kelompok yang lainnya. Fakta di lapangan tentang gerakan sosial korban lumpur lapindo juga menunjukkan identitas yang demikian. Pada tingkat individual, identitas memberikan seseorang lokasi personal sebagai titik pusat individual yang stabil dan mantap. Pada tingkat sosial, identitas sosial memberikan lokasi sosial pada sebuah kelompok sosial (Ibid).

Identitas, dalam hal ini, dibentuk melalui satu proses sosial. Sekali suatu identitas mengkristal, ia akan dipelihara, dimodifikasi atau bahkan diubah sama sekali melalui hubungan-hubungan sosial. Hal yang demikian juga berlaku bagi identitas gerakan sosial para korban lumpur, misalnya apakah nama kelompok, perasaan senasib sebagai korban dan berbagai narasi yang dibangun dalam perjalanan pergerakan.

Para pemimpin gerakan (Pagar Rekontrak dan GKLL) menyadari bahwa pembentukan identitas gerakan merupakan sebuah komponen penting dari setiap gerakan sosial. Proses ini bukanlah sama sekali merupakan sesuatu yang terberi dari sebuah struktur sosial. Basis dukungan bagi mobilisasi sebuah gerakan tidak tersedia secara alamiah dan otomatis, melainkan sebaliknya basis itu dari dirinya sendiri merupakan sebuah "konstruksi sosial" (Mirsel, Robert 2004). Sebagai sebuah konstruksi sosial, basis dukungan bisa saja mengarahkan sebuah gerakan menjadi agen bagi kelompok-kelompok yang merasakan adanya tegangan struktural, namun gerakan juga menciptakan basis dukungan bagi dirinya sendiri. Gerakan sosial korban lumpur lapindo dalam faktanya menggunakan Mobilisasi Sumber Daya di satu pihak dan produksi Identitas di pihak lain. Secara keseluruhan disampaikan simpulan dari Bencana industri tersebut di atas sebagai berikut:

\section{PENUTUP}

Pertama, tindakan kolektif warga korban lumpur Lapindo bukan hanya sebuah protes, melainkan suatu bentuk perlawanan atau gerakan sosial dalam melawan korporasi maupun negara yang keduanya menyatu dalam bentuk korporatokrasi. Tindakan kolektif ini sebagai gerakan sosial hanya berusia 5 tahun.

Kedua, tindakan kolektif warga korban lumpur lapindo adalah suatu gerakan untuk 
menuntut kembali atas hak-haknya yang selama ini telah hancur (dihancurkan) yang berupa tanah, sawah bangunan rumah dan lapangan pekerjaan, kebebasan, kemerdekaan, kesehatan dan pendidikan, kenyaman yang dirampas oleh bencana industri.

Ketiga, tindakan kolektif warga korban lumpur lapindo dan kepentingan (interest) merupakan aktualisasi dari hak-haknya yang paling dasar, hak atas pekerjaan, tempat tinggal, rasa aman dan nyaman. Pendek kata identitasnya yang lama hilang musnah, namun setelah itu identitas yang baru pun juga terbentuk dan mengkristal, walaupun masih terbuka akan perubahan-perubahan.

Keempat, tindakan kolektif dalam kaitan dengan MSD adalah suatu tindakan rasional, karena bersifat materiil. Setiap konstituen atau pengikut akan selalu berhitung akan untung rugi. Perspektif teori rasional ini, berlaku dalam diri individu, namun jelas tidak berlaku di dalam rasionalitas kelompok atau kolektivitas. Oleh karena itu secara individual tindakan kolektif adalah rasional, namun tidak berlaku rasionalis dalam kolektivitas.

Kelima, tindakan kolektif dan teori mobilisasi sosial, perlawanan melalui tindakan kolektif juga membutuhkan suatu mobilisasi, mobilisasi motivasi, mobilisasi sosial, mobilisasi sumber daya baik yang internal kolektivitas maupun eksternal kolektivitas. Mobilisasi ini dipadukan dengan produksi dan teori identitas. Sintesis atau paduan antara mobilisasi dan identitas ini dapat diintegrasikan ke dalam sebuah paradigma gerakan sosial dan aksi kolektif yang relatif koheren dan sinkretik, sejajar dengan garis perumusan yang disiratkan Habermas (Singh. 2010).

Keenam, tindakan kolektif dan proses perencanaan atau pembingkaian aksi kolektif, pembingkaian sebenarnya merupakan suatu aktivitas yang kompleks dan mempengaruhi keberhasilan suatu tindakan kolektif atau gerakan sosial. Pembingkaian sekaligus berkaitan erat dengan pembentukan narasi-narasi yang tidak mustahil ini menjadi suatu bentuk identitias kolektif tersendiri. Narasi ini pula yang dibangun dan disosialisasikan kepada semua konstituen dan simpatisannya.

Ketujuh, identitas kolektif dan Kepemimpinan Gerakan Sosial atau Perlawanan. Peran dan peranan pemimpin di dalam suatu gerakan sosial atau tindakan kolektif baik dalam bentuk perlawanan atau protes membutuhkan pemimpin sebagai aktor yang memberikan roh kehidupan suatu organisasi, maupun motor penggerak suatu organisasi gerakan. Sebagaimana Melucci (1989: Dalam Klandersmans. 2005) mengingatkan bahwa penciptaan identitas kolektif adalah salah satu tantangan fundamental yang akan dihadapi oleh para partisipan gerakan. Tetapi identitas kolektif tidaklah dihasilkan secara mekanis. Ketidakpuasan yang ditetapkan secara kolektif dan menunjuk kepada para pihak yang bertanggung jawab atas ketidakpuasan kolektif itu, menjadi suatu yang penting.

Kedelapan, identitas kolektif dan Gerakan Sosial Baru, tindakan kolektif dengan perangkatnya yang disebut identitas kolektif mampu memberikan sumbangan yang berarti bagi suksesnya suatu perjuangan. Karena itu David A Hollinger dalam Jurnal Daedalus menulis: "From Idendity to Solidarity" dari identitas menuju ke solidaritas (David A Hollinger. 2006). Identitas kolektif bukan semata-mata berisi segala sesuatu kebersamaan, melainkan juga suatu keberbedaan sekaligus menjadi identitas kolektif. Identitas kolektif dapat memberikan tambahan penjelasan baru atas gerakan sosial yang dilakukan secara kolektif.

Kesembilan, apabila tindakan kolektif dibanding dengan gerakan-gerakan sosial yang lain dapat dijelaskan bahwa tindakan kolektif menurut pemikiran gerakan sosial lama bermakna negatif sebagai anak nakal atau penyimpangan dari keteraturan masyarakat, namun menurut pemikiran gerakan sosial baru tindakan kolektif adalah suatu yang inheren dengan keteraturan masyarakat. Masyarakat yang pada dasarnya berisi tentang konflik yang bersifat laten. Hal ini juga terjadi di dalam perbanditan yang menurut suatu kelompok sebagai tindakan kriminal dan berdampak negatif dan dari kelompok yang lain perbanditan dipandang sebagai tindakan yang heroik dan terpuji (Suhartono. 1995).

Kesepuluh, tindakan kolektif dan Organisasi Gerakan Sosial. Mengutip pendapat Rajendra Singh, Prasetyo (2006) menyatakan salah satu karakteristik GSB adalah asumsinya bahwa masyarakat sipil tengah meluruh, ruang sosialnya mengalami penciutan dan aspek masyarakat sipil tengah digerogoti oleh kemampuan kontrol negara. Oleh karena itu 
GSB membangkitkan isu pertahanan diri yang juga berarti perlawanan dan atau tindakan kolektif (Fadilah Putra dkk. 2006). Asumsiasumsi itu semua faktanya dapat ditemukan dalam gerakan sosial korban lumpur lapindo.

Kesebelas, tindakan kolektif yang terjadi atas korban lumpur lapindo memiliki persamaan dengan proses penggusuran yang terjadi di Kebon Kacang sebagaimana hasil penelitian Jellinek. Perbedaannya jika di Kebon Kacang penggusuran dilakukan tanpa melibatkan alam, sedangkan di Porong Sidoarjo melibatkan kekuatan alam yang dipicu oleh gagalnya teknologi.

\section{DAFTAR PUSTAKA}

[1] Aditjondro, George Julius. 2003. Korbankorban Pembangunan. Tilik-an beberapa kasus Perusakan Ling-kungan di tanah Air. Yogyakarta: Pustaka Pelajar. Bagaimana peran mi-liter semasa Orde Baru dan sesudahnya diuarikan panjang lebar dalam "Negeri Tentara, Membongkar Politik Ekonomi Militer"Dalam Wacana. Jurnal Ilmu Sosial Transformatif. Edisi 17, Tahun III 2004. Yogyakarta: Insist.

[2] Akbar, Ali Ashar. 2012. Konspirasi SBYBakrie. Jakarta: Indo. Cf. Akbar. AA. 2012. Konspirasi SBY-Bakrie. Jakarta: Indopetro Publishing

[3] Berger dan Luckmann. 1990. Tafsir Sosial atas Kenyataan: Risalah ten-tang sosilogi Pengetahuan. Jakarta: LP3ES hal : 248

[4] Bert Klandermans. 2005. Protes Dalam Kajian Psikologi Sosial. Yogyakarta: Pustaka Pelajar

[5] David A Hollinger dalam Jurnal Daedalus menulis : "From Idendity to Solidarity" (Fall. 2006) 135, 4, Academic Reasearch Library, pg. 23

[6] Fadilah Putra dkk. 2006. Gerakan sosial. Malang: Averoes hal 65. Cf. Julian B. H. 2016. "Gerakan Sosial" Dalam Basis. Nomer 1-2, Tahun ke-65, 2016: h. 17-18

[7] Hotman Siahaan. 1996. Pembangkangan Terselubung petani dalam Program Tebu Rakyat Intensifikasi sebagai upaya Mempertahaankan Subsistensi. Surabaya: Program Pasca Sarjana h. 203

[8] James R. Rush. 2000. Opium to Jawa. Jawa dalam Cengkeraman Bandar-bandar Opium Cina, Indonesia Kolonial 1860-1910

[9] Kanal Edisi 1 Agustus 2008, diterbitkan oleh Kanal Korban Lapindo.
[10] Mirdasy, Muhammad. 2007. Bernafas Dalam Lumpur Lapindo. Surabaya: MIIP/Surya.

[11] Mirsel, Robert 2004. Teori Pergerakan Sosial. Kilasan Sejarah dan Catatan Bibliografis. Yogyakarta: Resist Book

[12] Nota Kesepahaman atau Mou pada dasarnya tidak lebih sebagai siasat Lapindo atas Perpres 14/2007;Cf. Sukamto. 2015. Menggurat, Meng-gugat, dan merajut Sejarah Sosial. Malang: UM Press.

[13] Noer Fauzi. 2005. Memahami Gerakangerakan Rakyat Dunia Ketiga. Yogyakarta: Insist h. 22. Cf. Prasetia. 2012. Bencana Industri. Depok: Desantara.

[14] Pichardo dalam Klandersman, 2005. Protes Dalam Kajian Psikologi Sosial. Yogyakarta: Pustaka Pelajar hal : 373).

[15] Piliang, 2011. Dunia Yang Dilipat: Tamasya melampaui batas-batas kebudayaan. Bandung: Matahari : 212

[16] Singh, Rajendra. 2010. Gerakan Sosial Baru. Yogyakarta: Resist Book. h. 437.

[17] Situmorang, Abdul Wahib. 2007. Gerakan Sosial. Studi Beberapa Perlawanan. Yogya karta: Pustaka Pelajar.

[18] Suhartono. 1995. Bandit-bandit Pedesaan di Jawa. Studi historis 1850 -1942. Yogyakarta: Aditya Media.

[19] Tarrow, 1998 dalam Situmorang. 2007. Studi Kasus Beberapa Perlawanan. Yogyakarta: Pustaka Pelajar hal : 35 